WORKSHOP ON EDUCATIONAL INNOVATION

IN ARCHITECTURE JIDA'17

JORNADES SOBRE INNOVACIÓ

DOCENT EN ARQUITECTURA JIDA'17

ESCUELA TÉCNICA SUPERIOR DE ARQUITECTURA DE SEVILLA 16 Y 17 DE NOVIEMBRE DE 2017 


\section{GILDA}

Organiza e impulsa GILDA (Grupo para la Innovación y Logística Docente en la Arquitectura), en el marco del proyecto RIMA (Investigación e Innovación en Metodologías de Aprendizaje), de la Universitat Politècnica de Catalunya - BarcelonaTech (UPC) y el Institut de Ciències de l'Educació (ICE). https://www.upc.edu/rima/ca/grups/gilda

\section{Editores}

Daniel García-Escudero, Berta Bardí i Milà

\section{Revisión de textos}

Rodrigo Carbajal Ballell, Silvana Rodrigues de Oliveira, Jordi Franquesa

\section{Edita}

Iniciativa Digital Politècnica Oficina de Publicacions Acadèmiques Digitals de la UPC

ISBN 978-84-9880-681-6 (UPC)

elSSN 2462-571X

D.L. B 9090-2014

(C) de los textos y las imágenes: los autores

(C) de la presente edición: Iniciativa Digital Politècnica Oficina de Publicacions Acadèmiques Digitals de la UPC 


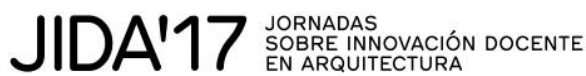

\section{Comité Organizador JIDA'17}

Dirección, coordinación y edición

\section{Berta Bardí i Milà (GILDA)}

Dra. Arquitecta, Departamento de Proyectos Arquitectónicos, ETSAV-UPC

Daniel García-Escudero (GILDA)

Dr. Arquitecto, Departamento de Proyectos Arquitectónicos, ETSAB-UPC

\section{Organización}

Rodrigo Carbajal Ballell (humAP)

Dr. Arquitecto, Departamento de Proyectos Arquitectónicos, ETSA-US

Jordi Franquesa (Coordinador GILDA)

Dr. Arquitecto, Departamento de Urbanismo y Ordenación del Territorio, ETSAB-UPC

Joan Moreno Sanz (GILDA)

Dr. Arquitecto, Departamento de Urbanismo y Ordenación del Territorio, ETSAV-UPC

Silvana Rodrigues de Oliveira (humAP)

Arquitecta, Departamento de Proyectos Arquitectónicos, ETSA-US

Judit Taberna (GILDA)

Arquitecta, Departamento de Representación Arquitectónica, ETSAB-UPC

\section{Comité Científico JIDA'17}

\section{Rodrigo Almonacid Canseco}

Dr. Arq., Dpt. de Teoría de la Arquitectura y Proyectos Arquitectónicos, ETSA Valladolid

Fernando Álvarez Prozorovich

Departamento de Historia y Comunicación, ETSAB-UPC

\section{Atxu Amann Alcocer}

Dra. Arquitecta, Departamento de Proyectos Arquitectónicos, ETSAM-UPM

\section{Silvia Blanco}

Dra. Arquitecta, Centro Superior de Estudios de Galicia, Universidad San Jorge 


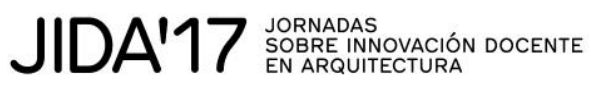

\section{Ivan Cabrera i Fausto}

Dr. Arq., Dpt. de Mecánica de los Medios Continuos y Teoría de Estructuras, ETSA-UPV

\section{Raúl Castellanos Gómez}

Dr. Arquitecto, Departamento de Proyectos Arquitectónicos, ETSA-UPV

\section{Nuria Castilla Cabanes}

Dra. Arquitecta, Departamento de Construcciones arquitectónicas, ETSA-UPV

\section{Eduardo Delgado Orusco}

Dr. Arquitecto, Departamento de Proyectos Arquitectónicos de la Universidad de Zaragoza

\section{Mariona Genís Vinyals}

Dra. Arquitecta, BAU Centro Universitario del Diseño de Barcelona

\section{María González}

Arquitecta, Departamento de Proyectos Arquitectónicos, ETSA-US

\section{Antonio Juárez Chicote}

Dr. Arquitecto, Departamento de Proyectos Arquitectónicos, ETSAM-UPM

\section{Juanjo López de la Cruz}

Arquitecto, Departamento de Proyectos Arquitectónicos, ETSA-US

\section{Nieves Mestre}

Dra. Arquitecta, Departamento de Proyectos Arquitectónicos, Universidad Europea

\section{Francisco Javier Montero}

Dr. Arquitecto, Departamento de Proyectos Arquitectónicos, ETSA-US

\section{Antonio Peña Cerdán}

Arquitecto, Departamento de Proyectos Arquitectónicos, ETSA-UPV

\section{Ana Portalés Mañanós}

Dra. Arquitecta, Departamento de Urbanismo, ETSA-UPV

\section{Amadeo Ramos Carranza}

Dr. Arquitecto, Departamento de Proyectos Arquitectónicos, ETSA-US

\section{Jaume Roset Calzada}

Dr. Físico, Departamento de Física Aplicada, ETSAB-UPC

José Vela Castillo

Dr. Arquitecto, IE School of Architecture and Design, IE University (Segovia, Spain) 


\title{
Aularch, an optional subject to introduce auscultation techniques in architectural studies
}

\author{
Zamora-Mestre, Joan-Lluís ${ }^{\mathrm{a}}$; Casas, Anna ${ }^{\mathrm{b}}$; Griera, Antoni ${ }^{\mathrm{c}}$; \\ Carnerero, Francesc ${ }^{d}$ \\ ${ }^{\mathrm{ab}}$ Departament de Tecnologia a l'Arquitectura, Universitat Politècnica de Catalunya, Spain, \\ ${ }^{\mathrm{c}} \mathrm{AG}$ arquitectura, Catalunya, Spain, 'Servei de Biblioteques de la Universitat Politècnica de Catalunya, \\ Spain
}

\begin{abstract}
This communication describes the introduction of an optional subject in architecture degree studies. The subject was designed to teachbasic skills in the use and interpretation of data from portable electronic devices for quick, affordable measuresof variables that are relevant to the behaviour of buildings,such as light, sound, heat and humidity. Since 2010, this subject has been offered by the Department of Architectural Technology, Vallès School of Architecture (ETSAV), Universitat Politècnica de Catalunya (UPC). The development of this experience has passed through several stages thathave all contributed to the creation of a model with sufficient maturity to be presented for discussion in the JIDA forum.

First, portable electronic devices were purchased. Such equipment is traditionally associated with research, and less commonly with the education of future professionals. Second, an optional subject taught by half a dozen lecturers was designed and offered to students, to transmit a core message regarding the possibilities of such tools. Third, the decision was made to deposit the equipment in the university library system, so that it wasmore widely available through library loans. Fourth, an agreement was signed with a professional company that has considerable experience in the use of this equipment, to give the experience a real dimension through practical cases. Finally, a collaboration agreement was drawn up with the local professional association of architects, so thatstudents who have passed this subject can apply their training in architecture companies that require these new skills, in order to complete the training cycle with job insertion.
\end{abstract}

Keywords: elective course, auscultation techniques, degree studies in architecture, non-destructive testing

Bloque temático 


\section{Introduction}

The university training of architects will be adapted in coming years to face new challenges in future professionals work, and changes in the tools available to them.

In Spain, the profession of architect is clearly regulated by a legal framework that has existed for over 200 years, which grants architects full, almost exclusive responsibility for the design and execution of all buildings for human use. This profession is accessed directly through a higher degree issued at the end of university studies, which is always verified and accredited by official bodies in the architecture schools of the Spanish public and private universities where these studies are taught. The curriculum should enable students to achieve competences in the relevant artistic, social, scientific and technical fields.

Clearly, future architects will work in more varied, unstable and complex environments than the generations that preceded them. The environmental component, in all its sub-dimensions, will also become increasingly important.

In order to train architects who can approach the problems posed by clients, institutions or companies effectively, the principles of rigor, precision and accommodation must be guaranteed using the available resources.

Since the 1990s, architectshave had the support of digital techniques to guarantee that these principles are met. The development of digital tools seems to have no limit, and embraces online communication networks, geolocation and the development of expert simulation programs.

One of the latest additions to this sum of digital media has been the design of portable devices for real-time, affordable, accurate measurements. Such tools can measurethe most relevant variables in architectural work, including humidity, sound, temperature and light. Some of these variables can even be measured directly by smartphones, due to the development of apps or esensors located in relevant locations of the building that can gather data regularly and store them or send them to the architect.

Due to the portability of these devices, the reduction in their cost and the connectivity of some of them to the internet, they are becomingessential to everyday decision-making. It is therefore the right moment to teach architecture students how to use them, and how to interpret the data that is gathered.

There are obvious benefits to introducing this training for undergraduate students, including the opportunities that it could lead toin the labour market. In Spain, certain signs of a turnaround in the previous expansion of the real estate sector are already evident. This situation, as well as the increase in the number of students who enter the profession each year,produce unemployment or various forms of underemployment. One way to generate employment for young architects is in the area of renovation and conversion of existing building stock; an option that will require greater specialization in the professional profiles of studentswho graduate from Spanish architecture schools in coming years .

\section{Methodology and results}

In 2010, the Universitat Politècnica de Catalunya (UPC) announced a call for applications for internal funding to improve teaching equipment. The Vallès School of Architecture (ETSAV) decided to apply for funds to purchase various portable digital measurement devices, instead of general equipment such as computers and static scientific equipment, or the physical adaptation 
of teaching areas. The initiative was supported by the Departments of Structural Architecture, Building Construction, and Nuclear Physics and Energy. It was therefore submitted as a joint application by lecturers from various areas of science and technology applied to architecture.

The text of the request stated the need to:

- Enhance students' understanding of the real behaviour of buildings

- Make new measurement tools available to students, so that they could verify and compare their initial designs

To meet these goals, digital portable equipment was requested that could be used in field measurement campaigns and support various subjects in the curriculum simultaneously. The aim was to use the devices to develop the following skills:

1. Measurement of properties of materials

1.1. Acquisition of data required for conducting experiments or assessing prototypes

1.2. Systematic recording and documentation of data

1.3. Correct expression of data and results

1.4. Use of measurement tools for conducting experiments or to assess prototypes

1.5. Calibration of measuring instruments

2. Experimentation

2.1. Preparation and verification of starting hypotheses

2.2. Application of suitable instrument techniques

2.3. Planning, design and execution of experiments

2.4. Treatment and interpretation of laboratory data

2.5. Analysis of data and evaluation of results

3. Modelling

3.1. Proposition, approach and selection of mathematical models that describe the results

3.2. Calculation or estimation of the parameters of the chosen model and adjustment to the data

3.3. Limits of the model, analysis and validity

The amount awarded was 16,000 euros, $4.58 \%$ of the total amount of funds in the call, a percentage that was in line with the ratio of ETSAV students within the UPC.

Finally, the following equipment was acquired: 


\begin{tabular}{|c|}
\hline 2 ut. SCHMIDT Sclerometer \\
\hline 4 ut. EXTECH HD 600 Sound Level Meter \\
\hline 2 ut. Hagner Screen Master \\
\hline 2 ut. Hygrometer of materials \\
\hline 1ut. FLIR I5 Thermal Imager \\
\hline 1ut. FLIR I7 Thermal Imager \\
\hline 1ut. Hygro-Thermometer + IR Thermometer RH 101 \\
\hline 1ut. Digital Psychrometer + IR Thermometer RH 401 \\
\hline 1ut. CFM / CMM Thermo-anemometer + IR thermometer AN100 \\
\hline
\end{tabular}

Table 1. List of initial portable equipment

Through other resources provided by competitive development projects in which the research group LiTA (Architectural Innovation and Technology Laboratory) has participated, the initial collection of equipment has been expanded.

\begin{tabular}{|c|}
\hline 1 ut. IRIScan book scanner \\
\hline 4 ut. Dynamic Digital Microscopes \\
\hline 1 ut. Proceq Resipod \\
\hline 1 ut. Proceq Ultrasound \\
\hline 1 ut. Moisture encounter plus by Tramex \\
\hline 1 ut. Moisture encounter CMEX II \\
\hline
\end{tabular}

Table 2. List of additional portable equipment 


\section{Training on the devices}

During academic years 2010-2011, 2011-2012 and 2012-2013, the optional AULA course was offered in the following format. Each session was conducted by a lecturer who presented a portable measuring device and illustrated the scientific basis of its working as well as and its field of application. The sessionended with the device being used, generally within the ETSAV building. The group work on a real practical case in the surrounding environment was designed to meet several objectives:

- To acquire data collection skills

- To become adept at formulating a behavioural hypothesis after the first interpretation of results

- To design a campaign that is extensive enough to test the hypothesis and compile consistent evidence that can be shared

As the results of the experience in the undergraduate curriculum were satisfactory, these devices were also made available to students of the university master's degree in Architectural Technology (UPC) for work on their final project. Learning was independent in this case, and expertise was gained by the intensive use of portable equipment, applied to the specific research topic developed in the project. Currently, the optional subject at undergraduate level has been relaunched with the new name AULARCH. This is due to several factors:

- A collaboration agreement has been signed between the Universitat Politècnica de Catalunya (UPC) and the external architecture firm AG, to disseminate the use of these device on the basis of the AULARCH platform. AG has previous experience in the use and development of these devices.

- The responsibility for teaching sessions has been limited to three lecturers, who are responsible for teaching about the devices with respect to structures, coatings and environmental conditioning.

- The process of loaning the devices has been established due to to the collaboration of the library service.

\section{Accessibility of equipment}

Until 2016, the equipment was only available on loan to the lecturers of the three university departments that were initially involved, for use in the optional subject AULA (code 47114: Auscultation of Architecture).

Subsequently, a new loan option was introduced for master's degree students who were working on their final projects. This change affected the intensity of the loan of devices as well as the duration of the loans. Therefore, it was agreed that the portable devices should be kept in the ETSAV building's care taker's office. This decision was taken as the office has a central location within the university building and is manned 24 hours a day by staff who are qualified to perform this task.

In 2016, it was decided that the equipment should be kept by the ETSAV Library service, in agreement with the institution's board and administration. This option was available because of three circumstances: 
- Similar,positive experiences in other UPC libraries

- A change in the direction of the library

- The experience gained in loaning laptops to students

\section{Professional use}

The AULARCH experience cannot be limited to the university environment, but must allow students to practice the newly acquired skills in the real world. As a result of the involvement of AG architecture, the AULARCH platform has contacted the local professional association of architects to establish a two-way future collaboration agreement:

- Allow students to gain experience in the use of these devices in real circumstances.

- Allow senior professionals access to these non-destructive techniques, by hiring students in an educational cooperation scheme, always guided by an academic tutor.

\section{Conclusions}

The AULARCH experience is now the culmination of a set of initiatives implemented from 2010 onwards to standardize the use of portable digital devices designed for auscultation techniques in architecture.

The AULARCH experience offers architecture students the opportunity to access and learn how to use portable measurement equipment, with instruction from university academic staff, and provides opportunities to use the devices in real situations.

The AULARCH experience allows students to acquire competences in the use of equipment that increases their ability to acquire information about the surrounding environment, interpret it, and put it at the service of their architectural design capacity. In addition, the use of these portable sensors can validate the goodness of designs in the course of their development.

The AULARCH initiative places architecture schools at the forefront of pedagogical innovation, adding new possibilities to the changes brought about by the digital revolution.

\section{References}

2013 ALCAÑIZ MARTÍNEZ, J. H., Ensayos y técnicas de obtención de información. Murcia : Universidad Católica San Antonio de Murcia http://cataleg.upc.edu/record=b1480199 S1 ${ }^{*}$ cat

2009 CALLISTER, WILLIAM D. Introducción a la ciencia e ingeniería de losmateriales. Barcelona: Reverté, 84-291-7253-X. https://cataleg.upc.edu/record=b1368018 S1* cat

2009 CÓIAS,V., Inspecções e ensaiosnareabilitação de edifícios Lisboa :Editora IST PRESS

https://cataleg.upc.edu/record=b1474373 S1* cat

2004 MALHOTRA, V. M., ed.Carino, Nicholas J., ed. Handbook of nondestructive testing of concrete. Boca Raton Fla. CRC Press

https://cataleg.upc.edu/record=b1474469 S1*cat 